\title{
Thomas Hobbes and a Chastened "Global" Constitution The Contested Boundaries of the Law
}

\author{
Anthony F Lang, Jr. \\ School of International Relations, University of St Andrews, St Andrews, UK
}

\begin{abstract}
Hobbes' account of politics, law and obligation has long been read, especially by realists in international affairs, as leaving no space for international law or institutions. This paper argues that a more nuanced reading of Hobbes' ideas about law and politics provides support for not only a defence of international law but a defence of a (chastened) global constitution. Hobbes' constitutionalism does not derive from a separation or balance of powers but on two other elements of constitutionalism: the importance of the individual and the centrality of law. The paper proceeds as follows: The first section locates Hobbes theory of law in relation to his theory of authority, drawing on David Dyzenhaus's emphasis on the rule of law in Hobbes. The second section draws on theorists such as Larry May to find a defence of international law and institutions, what I call international constitutionalism. The third section turns to Richard Flathman's interpretation of Hobbes as a theorist of liberal self-making, suggesting how his insights can be applied globally. The conclusion brings these thoughts to bear on the relevance of Hobbes for global law and politics.
\end{abstract}

Keywords: Thomas Hobbes, liberalism, David Dyzenhaus, Larry May, Richard Flathman, global constitutionalism

\section{$\underline{\text { Introduction }}$}

According to scholars of International Relations (IR), Hobbes has long been the archetypical realist. This view usually relies on two quote from Leviathan, both from the $13^{\text {th }}$ Chapter of Book I: First, the idea that life in the state of nature is 'nasty, brutish, and short', i.e. without some authority structure individuals will simply pursue their interests with no regard for rules of laws (Hobbes 1968 [1651], pp. 186); second, the infamous sentence, also from Leviathan, in which Hobbes claims that sovereign political communities are no more than 'gladiators' pointing their weapons at each other (Hobbes 1968 [1651], pp. 187-188). Realists see here a Hobbes who reinforces their view that the international order is an anarchic one with no place for institutions and laws.

\footnotetext{
*Email: al51@st-andrews.ac.uk
} 
As with any author, a simplistic reading is often based on the interpretative assumptions brought to the text, a failure to read more widely than a single quote, or a disciplinary background that selectively explores a few themes rather than a wider argument. All of these background conditions can be found in the IR reading of Hobbes. The fault is not only with realists, however, but with critics of realism as well.1 Certainly, there are dimensions of Hobbes' thought that lend themselves to such a reading. Hobbes did indeed see political life as a constant struggle to ensure peace by creating a powerful sovereign.

In this article, I suggest an alternative reading of Hobbes, one that finds in his work a defence of both international law and global constitutionalism. This reading relies on interpretations of Hobbes from David Dyzenhaus, Larry May and Richard Flathman. Dyzenhaus has argued in a number of places that Hobbes should be read as a theorist of constitutionalism because of the strong emphasis on the rule of law in his framework. May's reading of Hobbes theory of constitutional contract and equity point to how he can be read as defender of an international legal and institutional order. Flathman argues for a Hobbes whose focus on the individual results in a powerful foundation for an alternative international order. From each one of these theorists (supplemented by a few others), I develop an account of Hobbes as a theorist of global constitutionalism, one whose insights into the intersection of law and politics in any political order points to a new way of seeing the global constitutional order.

International law relies on the interests of states (Koskenniemi 2005). The origins of this tradition can be found in numerous places, from the raison d'etat of Machiavelli to the idealism of Hegel. This statism parallels the statism of realism, making both subject to a failure to take into account the individual person's role in international and global affairs. Of course, practically, the global level prevents us from seeing and conceptualizing the individual, much less finding any political agency for individuals. Alternatives to this statist 
international legal order have emerged in recent years. The first can be found in the effort to re-envision international law and politics through cosmopolitanism. This approach focuses on the individual as the primary point of consideration in the construction of alternative political orders at the global level. Cosmopolitanism can be found across a range of different philosophical and political theorists. Perhaps the most influential in those seeking to locate a cosmopolitan orientation through international law can be found in the figure of Immanuel Kant (Brown 2009, Habermas 2006). There is a strong individualist orientation in cosmopolitanism. And, as with Hobbes, Kant is often located in a particular tradition of thought within IR, one that is alternatively labelled idealist, utopian or liberal. Indeed, one critique of this literature is that it fails to locate cosmopolitan potential in actual international legal and political practices.2

The second comes through the literature on global constitutionalism. Global constitutionalism argues that there exist emerging patterns and practices in international law and politics that can be read as instances of constitutionalism, broadly defined. These new practices and patterns can be found in a renewed emphasis on the rule of law; the creation of new judicial institutions; calls for the separation of powers in international institutional frameworks; and the role of protest and revolutionary actions by non-state actors in response to the powers of states and international organizations. Global constitutionalism finds space for the individual in the global order in ways that traditional international fails to do. It is a normative framework for re-envisioning international law and politics.

Hobbes provides resources for thinking about an individualist global order that does not fall victim to the utopianism of much of cosmopolitan thinking but can be located in a constitutional framing. To make this Hobbesian alternative more concrete, I propose here a chastened global constitutionalism, borrowing the idea of chastened individualism from Flathman's reading of Hobbes. Hobbes is not normally considered a theorist of 
constitutionalism; his aversion to dividing sovereignty makes ideas such as separation and balance of powers less amenable to a Hobbesian account. But his writing on law (Dyzenhaus and Poole 2012) make him a useful theorist of a political order that is essentially legal. And, his focus on peace, a focus often ignored by realist interpreters, makes him directly relevant for conceptualizing both international and global constitutionalism. The combination of his legalism and liberalism make Hobbes a surprisingly important and useful theorist for articulating one version of global constitutionalism.

The article proceeds as follows: The first section provides a reading of Hobbes' key arguments that highlights the importance of law and individualism, drawing on the work of David Dyzenhaus. The next section turns to Hobbes as a theorist of international law and institutions, what I call international constitutionalism, through Larry May's recent reading of his work. The section that follows turns to the individualism of Richard Flathman's reading of Hobbes, one which contributes to seeing the role of individuals as self-makers. This leads me to the conclusion in which I highlight the importance of law making in global constitutionalism. Rather than focusing on judicial activism as much of the literature on global constitutionalism does, I conclude with an emphasis on law making, something that theorists of global constitutionalism need to explore in more depth. Hobbes' individualism and legalism provide resources for highlighting this more neglected dimension of the current and future global order.

Authority and Law

Let me start by saying something about Hobbes ideas concerning authority, for his theoretical apparatus is, I would argue, largely about the way in which we can justify an authority structure.3 As is well known, in Leviathan (1651) Hobbes sought to develop an argument that would explain why individuals should abdicate their rights to a powerful sovereign. Hobbes argued that without the Leviathan society could not function. Not only 
would social and political norms be overridden, normal social intercourse and even language would not be possible. While he emphasized the sovereign's absolute authority, it is important to remember that Hobbes' ideas of governance and authority are grounded in a liberal conception of the human person, that is, one that relies upon the rights of individual persons (Strauss 1936). The nature of the human person, however, produces the need for a sovereign to whom those rights will be abdicated. Those individuals pursue power in order to protect themselves since they have an equal ability to kill each other (Hobbes 1968 [1651]: 183). This description of the human person leads Hobbes to propose a series of natural laws, the first two of which are the most important: First, every man seeks peace. Second, every man will defend himself (Hobbes 1968 [1651]: 190-193). The result of these natural laws is that man must submit to a sovereign authority that will ensure the protection of all.

That sovereign has authority over all members of the society, the result of a contract of sorts among individuals in a society. That contractual relationship leads members to create an authority to which they owe their allegiance. That authority manifests itself in the ability of the sovereign to issue commands. Commands are orders expressive of the will of the sovereign and are authoritative for this reason. Laws derive their force from being commands of the sovereign which Hobbes differentiates from counsels, which are orders to obey based on reasons for what would be good for the individual (Hobbes 1968 [1651]: 303).4 This distinction is central to Hobbes' conception of obligation. I am obliged to follow the dictates of the sovereign not because he gives me reasons to do so, but simply because he has ordered me to do so. If the sovereign is forced to justify his orders and debate with individuals, then his authority is weakened. This obligation to obey the sovereign is, ultimately, grounded in Hobbes' natural law arguments - obedience is necessary to protect us from each other, a point that arises from Hobbes' natural laws, particularly the first two. But, once we have entered into the contract with the sovereign, we no longer need to have our obedience 
justified by reference to those reasons but simply because the sovereign wishes it to be that way.5

Authority is not a simple matter for Hobbes, for it must both make sense of why individuals should obey and also how to make authority concrete. Law is the means by which both tasks are accomplished. That is, a law governed order is one that prevents an authority figure from governing without any limits or whimsically, hence respecting the agency of the individual as in need of some order, and it also makes specific the ways in which commands come about. Hobbes defines law as: 'A Law is the Command of him, or them that have the Soveraign Power, given to those that be his or their Subjects, declaring Publickly, and plainly what every of them may do, and what they must forbear to do' (Hobbes 1971 [1681]: 71). So, while the realist picture of Hobbes described in the opening pages of this article would imply that nothing can limit the sovereign power, law, while not a limit on authority, is fundamental for making authority work.

While law makes authority function, Hobbes does not see a benefit in limiting that authority. To do so is to allow the possibility of division and ultimately war. As he states clearly in one of his earlier works, Elements of the Law: 'The division of sovereignty, either worketh no effect, to the taking away of simple subjection, or introduceth war; wherein the private sword hath place again' (Hobbes 2008 [1640]: 116). The passages that follow, though, do leave space for a pragmatic division of labour in governing, noting that there is space for monarchy, aristocracy and democracy in the practice of government (ibid). This division is not designed to limit the sovereign but to make it possible for the sovereign to govern in order that a political order can work effectively to accomplish that most important of aims: the creation of peace. 6

Hobbes' understanding of law, then, is directly related to his understanding of authority and sovereignty. He defines law by means of sovereignty, as in Leviathan, Chapter 
26, Of Civil Law: 'CIVIL LAW, Is to every Subject, those Rules, which the CommonWealth hath commanded him, by Word, Writing, or other sufficient Sign of the Will, to make use of, for the Distinction of Right, and Wrong; that is to say of what is contrary, and what is not contrary to Rule' (Hobbes 1968 [1651]: 312). As he goes on to explain the Commonwealth is nothing but the Representative, which is the Sovereign. This view of law stands in contrast to two alternatives. First, the natural law tradition posits that law derives from the application of right reason to the human condition. Hobbes begins his reflections on law through an engagement with the idea of natural law. In Leviathan, Chapters 13 and 14 elaborate the human condition and the resulting natural laws. And, in Chapter 26 in which he explains the civil law, Hobbes states that 'The Law of Nature, and the Civil Law, contain each other, and are of equall extent' (Hobbes 1968 [1651]: 314). Martin Loughlin argues that because Hobbes saw himself as providing a justification for authority and law, he needed to address natural law in some way. Rather than re-establishing natural law in its traditional form as the basis for civil law, Loughlin suggests that 'Hobbes made natural law a central focus of his work... in order to expose its errors and rework its precepts for the purpose of rebuilding the authority of sovereign will' (Loughlin 2012: 12).

The second alternative to Hobbes' account is that of the common law. In both Leviathan, Chapter 26 and in the Dialogue, Hobbes argues that the history of a custom or the wisdom of judges cannot be the basis for law or our obligation to obey it. Against those who would argue that the ancient heritage of law is what gives it validity, Hobbes states: 'When long Use obtaineth the authority of a Law, it is no the Length of Time that maketh the Authority, but the Will of the Soveraign signified by his silence, (for Silence is sometimes an argument of Consent;) and it is no longer Law, then the Soveraign shall be silent therein' (Hobbes 1968 [1651]: 313). And, further, in response to Edward Coke's defense of the role of the long study and wisdom of the common lawyer: 
For it is possible long study may encrease, and conform erroneous Sentences; and where men build on false grounds, the more they build, the greater is the ruine; and of those that study, and observe with equall time, and diligence, the reasons and resolutions are, and must remain discordant: and there it is not that Juris prudientia, or wisdom of subordinate Judges; but the Reason of this our Artificall Man the Common-wealth, and his Command that maketh the Law: And the Common-wealth being in their Representative but one Person, there cannot easily arise any contradiction in the Lawes; and when there doth, the same Reason is able, by interpretation, or alteration, to take it away. Hobbes 1968[1651]|: 317

Neither history nor wisdom can give the common law the authority that it deserves, but only the sovereign legislator can give it that authority.

Reflecting on the authority of law leads one to the question of constitutionalism. For some, Hobbes is a constitutional theorist, for he gives a strong defense of the rule of law. David Dyzenhaus, for instance, argues that Hobbes' constitutional theory is 'a theory of fundamental principles of legality which does not fit neatly into our contemporary categories of legal positivism and natural law. Indeed, it seems to me that we can make better sense of Hobbes as an early theorist of the rule of law tradition, whose members hold that the ultimate constitution of political order is legal and not political' (Dyzenhaus 2010: 456). Those who see constitutional as about a separation and balance of powers would not see Hobbes as a theorist within this tradition, but Dyzenhaus and others who privilege the rule of law as the primary criterion of a constitutional order can find in Hobbes resources to defend their position.

Dyzenhaus argues that Hobbes also provides a resource for defending an international rule of law. Unlike the majority of interpretations of Hobbes on international affairs, Dyzenhaus focuses on the centrality of law in Hobbes account of all political life, domestic and international. He points to the fact that the existence of the sovereign results not from an aggrandizement of power by any individual but that it results from a fundamentally legal project: 'Submission to a sovereign is not submission to the arbitrary rule of one person. It is submission to the rule of one artificial person whose identity is legally constituted and who 
not only rules through law but in accordance with the rule of law. Submission to sovereignty is ultimately submission to the rule of law' (Dyzenhaus 2014: 55). While not suggesting that the international community of states has created a sovereign leviathan by which they can be governed, Dyzenhaus does propose that the international laws made by states bind them in some fundamental way. They are bound because by accepting their status as states, they have accepted the fact that they must act in accordance with and justify their arguments in terms of international laws. The act of making is not an act of making the sovereign that the domestic community has undertaken but the act of creating a body of laws that define the nature of the international order.

Hobbes' understanding of law relies on his understanding of sovereign authority. The sovereign, the artificial person created by the community, serves as the legislator, executive and judiciary. That sovereign must retain all these roles in one to prevent the anarchy and war that would result from individuals pursuing their own interests. And, while Hobbes admits that the international realm looks closest to this anarchy, he does not necessarily see international law or order absent at the global level.

\section{$\underline{\text { International Constitutionalism }}$}

Dyzenhaus presents a Hobbes who privileges the rule of law, hence making him a theorist of constitutionalism. Dyzenhaus makes the further argument that this emphasis on law in Hobbes account is relevant not only at the domestic but at the international level as well. This element of constitutionalism is, of course, one part of the ideology of constitutionalism. Constitutionalism is the political philosophy that proposes political life should be law governed and that no one actor should be able to dominate a political order. A constitution is a purposefully constructed political and legal text that sets out the details of such a system is to be ordered. Not all constitutional political orders have a written constitution and not all constitutions embody the norms of constitutionalism. The written 
constitution is the product of the $18^{\text {th }}$ century revolutions in the United States and France, building on the charters of the English colonies in America and the Dutch republic of the $17^{\text {th }}$ century. Hobbes is usually not seen as a theorist of constitutionalism, for he resisted efforts to divide and limit the sovereign, though Dyzenhaus makes the case that his focus on the rule of law is evidence enough for a constitutional reading. Indeed, this legalistic reading has become the more prominent theorization of constitutionalism in recent years, perhaps best represented in the work of Ronald Dworkin, whose emphasis on rights and judicial review has structured much of the legalism around constitutional theory (Dworkin 1977).7

Outside of this rule of law constitutionalism, Larry May provides another reading of Hobbes that points to the potential for a political reading of his constitutional theory. May, drawing on the Dialogue and other elements of Hobbes' corpus, makes two relevant arguments in relation to constitutionalism. First, he explores Hobbes social contract theory, in which he differentiates a social contract from a constitutional one. The former is a contract made among those who live in a natural state of potential conflict, and their agreement to constitute a political order requires all to consent to join. The latter, though, is closer to what we would think of as a constitutional arrangement. This is a contract that stipulates more clearly what kind of governing order should exist. May locates this distinction in the difference between Chapters 17 and 18 of Leviathan, in which the former chapter clarifies how a commonwealth arises from a multitude and the latter chapter clarifies the kinds of powers that the constituted sovereign holds. Most interpretations of Hobbes do not highlight this distinction, but May nicely brings out the point that while each individual must consent to the construction of the commonwealth, not all are necessary to the specifics of what he calls the 'constitutional contract' (May 2013: 48-66).

The limit on the sovereign, though, comes not from the constitutional contract alone but from the concept of equity. May argues that this concept is central for Hobbes' idea of a 
moral limit placed on the sovereign than is the concept of justice. For every reader of Hobbes knows that justice is defined by the sovereign and can only be found in the positive laws that the sovereign passes. But equity, as May presents it, is the procedural dimension of fairness that comes out most clearly in the Dialogue. May suggests that Hobbes found in the Courts of Equity that existed in England in his day a model for how a court might exist to hear complaints against the sovereign. The idea of equity does not override the sovereign, but only serves to 'correct' him, a point that Hobbes makes to differentiate his view from Edward Coke, the champion of the common law against which Hobbes positions the Dialogue (May 2013: 79). Yet this corrective role is an important one, according to May, for it does place important limits on the sovereign's actions. May argues that equity is primarily a principle of procedure, a point that he argues makes Hobbes' view on law and politics similar to Lon Fuller's quasi-natural law theory (May 2013: 137-138).

These two elements of May's argument, the idea of a constitutional contract and the idea of equity, come together in his reflections on Hobbes and international law and institutions. May's book concludes with a defence of Hobbes as a theorist of international law and institutions against the views of those realists who only quote the famous sentence from Chapter 13 in which states are nothing more than gladiators facing off with each. May argues that even this passage allows space for an association of states that might seek to provide for the welfare of their peoples (May 2013: 182-183). This space is constrained, of course, for it is composed of states rather than being a commonwealth of peoples. As such, May continues in this vein to argue that international law, made by states, and international institutions, composed of states, can both be justified in accordance with Hobbes' theories. Moreover, the centrality of equity in May's interpretation gives him resources to justify an international legal code governing the conduct of war, such as that found in the Hague and Geneva Conventions and enforceable (to some extent) in the International Criminal Court. 
We can connect May's account with the emphasis that Hobbes places on peace. As noted above, the first natural law listed by Hobbes in Leviathan is that all men should seek peace. The state is constructed, according to this reading, for this primary purpose, that of creating a peaceful political order. While realists tend not to highlight this element of Hobbes' thought, it is directly relevant to the construction of international law and institutions. One need only look at the United Nations Charter to see how central peace. Bardo Fassbender has argued that the UN Charter provides a kind of proto-global constitutional text, and he highlights the centrality of peace as the master concept in reading that text (Fassbender 2009). While Fassbender does not draw on Hobbes, we can certainly make the link between the emphasis on peace in Hobbes theories and the way in which international law and institutions privilege this idea.

May's account of Hobbes leads to what I would call an international constitutionalism, or one in which states are the primary agents, authorized to protect their citizens through the construction of Leagues and laws that govern their relations. This provides us with a further step toward seeing Hobbes as a theorist of global constitutionalism. Yet, in order to make the step toward a truly global constitutional order, we need to move beyond the international constitutionalism toward something more deeply integrated into the individual lives of those who inhabit the globe. This step might seem impossible in accordance with Hobbes' theories, for he does not seem interested in the role of individuals but only in the role of the institutions designed to protect individuals from each other. But, one further reading of Hobbes which privileges the individual and connects that individualism to a critical form of liberalism, can provide us with the resources we need to move toward a global constitutional order.

\section{Global Constitutionalism}


Thus far, I have argued that Hobbes theory of law rests on a clearly defined conception of authority. Hobbes' emphasis on authority does not lead to dictatorship or authoritarianism (though it might) but rather relies on the rule of law in order for true political authority and order to come about. The link between authority and law makes a turn to constitutionalism possible, for it is a constitution that brings together the political and the legal. Hobbes, as noted above, does not easily fit into liberal constitutionalism, though, for he eschews any separation of powers in order to limit the government, which he believes would lead to a descent into chaos and anarchy. Larry May’s reading of Hobbes suggests how we might see some limits placed on the sovereign, through the idea of equity and a reading of the social contract as a constitutional contract. Along with the importance of peace, we can find in Hobbes a theorist of international constitutionalism as an extension of international law and institutions.

Yet there are resources in Hobbes for a different element of constitutionalism, that of constituent power, one that can connect Hobbes to what I would argue is a fuller form of global constitutionalism. This is an unlikely claim to make, for Hobbes' theory of the social contract comes in a single moment of founding after which individual members of the community would seem to fade into a quiescent mass that simply follows their leader. This reading of Hobbes does not value that strong individualism at the heart of his theories, an individualism that connects in important ways to his legal theory. Moreover, this individualism leads to an aspect of Hobbes' thought that demonstrates the potential for a global constitutionalism arising from the purposeful actions of liberal individuals seeking to promote and protect forms of order that benefit themselves and others - that is, Hobbes' individualism and theory of self-making provides a foundation for how global constituent powers might coalesce into forms of global constitutionalism. 
My reading of Hobbes' individualism comes from Richard Flathman. Flathman has developed an account of authority, rights and liberalism that privileges a strong individualism. His early work drew upon analytic political philosophy to flesh out key concepts in liberal theory, primarily rights and authority (Flathman 1977, 1980). From these and other works, he has constructed an account of what he calls 'wilful liberalism', a liberalism based on a strong individualism that verges on the anarchic but shies away from embracing this position fully (Flathman 1989, 1992, 1998). Instead, his liberalism is one in which individuals demand justification for authority, assert their rights, and remain impenetrable to each other. This fundamental impenetrability, one that results from the human condition of being unable to fully understand and appreciate each other, leads not to chaos and self-interested behaviour, but in Flathman's account can lead to a greater respect for others, a respect for the rights of others, and a cultivation of a kind of fundamental pluralism (Flathman 2005; Honnig and Mapel 2002). As should be evident from these themes, Thomas Hobbes has played a crucial role in Flathman's development of his account of liberalism.

Flathman's account of Hobbes brings together many of the themes noted above. Rather than transposing contemporary theories onto Hobbes, however, Flathman undertakes a thorough reading of Hobbes' work, across not just the political texts but those in the realm of the natural sciences as well. Indeed, it is those works on natural science, particularly on the composition of the universe in which we live, that Flathman begins: 'Hobbes's writings depict a densely material universe pulsating with energy and movement but largely lacking in humanly intelligible or serviceable order or purpose' (Flathman 2002: 1). Whatever order and purpose do emerge from this universe, particularly when it comes to those things pertaining to the human condition, results from what Flathman calls 'human making'. This human making begins in ourselves, where the passions and rationality work together to construct and 
make our reality. Unlike many other theorists, for whom the passion must be tamed and controlled, Flathman's Hobbes finds the passions essential for making. They link with imagination, a crucial component of our lives, that element which allows us to think across new vistas and create new realities. This role for the passions, imagination and reason does not necessarily lead to peace and concord, though, but provides a spur to new thinking and creative possibilities: '[Hobbes] regarded the passions as well as the imagination as essential to all effective thought and action and indeed as the dominant party in the perpetually unstable array of forces responsible for both peace and disorder, both great achievements and horrific failures' (Flathman 2002: 20). Language, reason and science bring these modes of thought and action under some semblance of control, or at least allow us to interact with and understand each to some extent. Hobbes believed his theories could give some order to this scientific endeavour, for he argued against those who would distort our ability to clarify the meaning and scope of scientific inquiry. At the same time, Flathman argues that within Hobbes' efforts there remained a deep scepticism about our ability to understand each other even when using the same words and language. This scepticism and lack of understanding is not necessarily resolved by giving the Leviathan the ability to define and control meanings, though this certainly ameliorates it to some extent.

Based on this reading of Hobbes' natural science, Flathman turns to their relevance for political life. Reminding us of Hobbes first two natural laws (Hobbes 1968 [1651]: 190193), Flathman contends that there are two modes of self-making possible in Hobbes' account. The more well-known is the creation of the Leviathan, a governmental authority that allows for the creation of peace by preventing self-interested persons from harming each other. But he highlights the other, individualistic form of self-making that Hobbes proposes. Persons must seek to cultivate in themselves certain virtues, ways of being that will allow them to live with each other commodiously. For most, this means prudence, a form of 
moderation that prevents us from overreaching and harming each other. But for some, there is also the cultivation of attributes such as magnanimity, gallantry, and generosity. These forms of self-making get less attention in commentaries on Hobbes, but Flathman argues that are crucial to undermining the view that Hobbes is a pessimist about human nature. Rather than seeing individual humans as evil or bad in their pursuit of their interests, Hobbes wants them to cultivate forms of the self that will allow them to pursue their interests but in a way that recognizes the reality of a human condition of scarcity and equality of ability to harm others. The Leviathan, then, is not the only answer to the problem of the human condition, though it is an essential one when individuals to not engage in the forms of self-making that Hobbes sees as a way to retain our strong individuality and live with others.

Flathman thus finds in Hobbes resources for a strong individualism. Hobbes, he concludes, feared democratic governance because it in this form of political life that there is the most threat to individualism and liberty. While the monarch may be flawed and thus construct a flawed political order, an active and animated demos will encourage the 'vainglorious' who will seek to appear before all others as most important and hence try to outdo each other with activity. 8 For Hobbes, and Flathman, this tendency in democratic life is to be feared more than the possibility of a single unconstrained sovereign, whose political reach is limited. Rather than turn toward a democratic structure that feeds the competitive spirit in public life, Flathman highlights those elements of Hobbes in which education is central. Civic education is where forms of character building can take place that might lead to the attributes identified as creating more possibilities for peace (Flathman 2002: 154; see also Slomp 2000: 173). 9

One accounts of Hobbes either draw on or parallel Flathman's reading, both of which provide re-readings of the Hobbesian international tradition. Michael Williams draws on directly on Flathman in reconsidering IR realism as a form of wilful liberalism, reading 
Hobbes, Rousseau and Morgenthau as representative of this idea. Williams disputes the realist assumption that the human condition or agents (either persons or states) are inherently given. Rather, he proposes, like Hobbes, that agents are made through conscious decision making practices that result from recognizing the inability to know each other, that scepticism that emerges in Flathman's reading as well. But this scepticism does not lead to anarchy or nihilism in either domestic or international life. Rather, for Hobbes, this scepticism prompts us to recognize our 'limits' leading to a kind of 'chastened' political life (another concept drawn from Flathman's reading - Williams 2005: 49). Williams takes this reading of Hobbes, along with Rousseau and Morgenthau, to construct an international politics of limits and constrained political action at the global level. This means pursuing interests but without certainty, a practice he finds lacking in so much of international politics.

A more recent reading of Hobbes also mirrors Flathman's, though this one does not draw on him directly and looks instead to Hobbes theological writings. William Bain, also in an effort to rethink Hobbes as a theorist of realism, suggests that he should be read as a voluntarist theorist in the medieval theological sense. He highlights how Hobbes' theology relies on a voluntarist God, one who makes and unmakes in accordance with his will and not in accordance with a pre-existing natural law or natural reason. In fact, there are no connections among things in this world, for they exist in that state of 'singular existents, things that are unrelated in any intrinsic way' (Bain 2014: 26). The order that exists in nature comes from God's imposition, his decision to create order out of chaos. Hobbes is a theorist of anarchy, Bain concludes, but not the anarchy of IR theory. Instead, this is an anarchy that invites acts of artifice and making, ways of reclaiming the world. Just as God orders nature, so humans can order political life - at either the domestic or global level: 'So as God imposes order on the heavens, fashioning the unity and regularity of the solar system, man imposes order on a state of nature composed of individual men, thereby fashioning the unity and 
regularity of a commonwealth... Man's creative potential, the ability to construct a stale pattern of human intercourse, is what saves him from the unrelenting misery of perpetual violence' (Bain 2014: 27). The individualism of Flathman is not directly invoked here, but a parallel account can be found in his defence of the singularity of existence, one that can only be tamed by God in the natural world and the human person in the political world.

In both Bain and Williams we see how some of the themes that Flathman has developed in his reading might be applicable at the global level. From all three, we find a theorist of artifice and making, a theorist who suggests that only when we take control of our lives and provide the order we need can there be peace. This wilful liberalism, strong individualism, and sceptical theory of limits leads can lead us to law and institution making. Just as in domestic political life we make the Leviathan to constrain and control us, so in global political life we can make and construct similar institutional structures.

To bring this discussion back to global constitutionalism, one might consider different elements of self-making at the global level that can fruitfully draw on Flathman's reading of Hobbes. The creative and imaginative dimension that Flathman draws from Hobbes might be helpful in thinking about imaginative alternatives to the current international order. For instance, the recent argument of James Tully that on global citizenships provides one possibility. Tully has long been a creative and insightful interpreter of John Locke, who, along with Hobbes, helped shape our understanding of rights in a liberal order (Tully 1993). But he critically reads Locke and the entire tradition of Western constitutional theory, as failing to account for alternative communal formulations, ones that do not allow for a plurality of voices at the global level (Tully 1995). His political theory of citizenship then begins in liberalism, but expands it outward. In particular, Tully reads efforts to engage with environmental issues and concerns as evidence of a new kind of citizenship, what he calls 'diverse citizenship' and which locates at the intersection of the local and the global (Tully 
2014). Creatively, Tully sees these efforts at self-making as leading to a new form of citizenship, something that can contribute to a global political and legal order. Tully does not draw on Hobbes, but I read in his efforts the kind of political practice and self-making I have drawn from Flathman's reading of Hobbes. This global citizenship connects to some important strands in the literature on global constitutionalism, though it is also distinctive in that it provides a new way to see the role of the individual in the global order.

One might also read into this Hobbes of making and artifice as a theorist who can help connect back to May’s defense of international constitutionalism. For May, Hobbes provides us a philosophical defense of such institutions and legal frameworks as limits on sovereign states. While I find this reading persuasive, I think May's account can be pushed even further in that individuals must play the role of making and creating when new institutions need to be created. For instance, though there are many theories that explain the creation of the European Union, one cannot ignore the crucial role played by creative diplomats such as Jean Monnet, whose efforts and vision was essential to seeing the European Coal and Steel Community as more than simply a functionalist means for ensuring energy supplies in Europe in the immediate post war era. The creative act of making new institutions continues as is evidenced by the role of international lawyers and diplomats in the creation of the International Criminal Court through the invocation of the Rome Conference in 1998. Anne Marie Slaughter suggests that this institution, along with many others, arose from individuals engaged in the construction of networks of information sharing and harmonization that enabled jurists, diplomats and politicians to come together to form a new element of the international judicial architecture (Slaughter 2004: 148-150).

Finally, it is important to remember the 'chastened' dimension of Hobbes' ideas about law and politics. Hobbes is not Kant, as he does not envision a progressive enlightenment of the human condition such that it will recognize the importance of law and justice at the 
domestic than global levels. Rather, Hobbes recognizes the dangers of the human condition, though he should not be read as a simple theorist of a sinful human nature causing these problems. Instead, Hobbes believes we can continually make and remake our institutions to achieve the peace and concord necessary for our shared life to continue. Williams helpfully reminds us that there are strands in realist thought that are not simplistic dismissals of the possibility of cooperation and peace, but that we can have a chastened perspective on global political life. This means not believing that each and every new institution or legal development will create universal peace and justice. It means, instead, being aware of the problems of political life but not abandoning the possibility of making and remaking our political lives at the domestic and global levels.

\section{$\underline{\text { Conclusion }}$}

This article began with the idea that Thomas Hobbes might be more helpful in understanding global constitutionalism than he is normally seen to be. Rather than a pessimistic theorist of a flawed human condition, the reading I have undertaken here presents Hobbes as a theorist of making and artifice, one who privileges the individual as the source and potential for new institutions in political life. Building on Dyzenhaus' primary on the rule of law, May's emphasis on equity in international law and institutions, and Flathman's emphasis on self-making and individualism, I have found in Hobbes an able defender of a form of global constitutionalism. It is certainly not a simplistic global constitutionalism, but a nuanced and chastened one, one that grows out law, institutions, and individuals and finds in the practices and activities of individuals around the world a potential for a new global political and legal order. 


\section{Acknowledgements}

Thanks to James Tully for an insightful reading of this paper and Gabriella Slomp for informative discussions of the matter within. All errors are my own.

Notes

1- See, for instance, Charles Beitz use of Hobbes (1999).

2- Though some have argued for a more realist cosmopolitanism; for examples, see Beardsworth 2013 and Hayden 2005.

3- My ideas about authority are largely shaped by two works; Richard Flathamn's book (1980) and Hannah Arendt's essay (1961). For my use of them, along with Hobbes and Locke, see Lang 2014: 20-42.

4- See Gabriella Slomp's article in this special edition for an argument as to how counsel is an essential part of the law making process.

5- Of course, Howard Warrender argued for a different foundation for obligation in Hobbes, one based on divinely based natural law (Warrender 1957). Obligation is more complex than I am presenting it here, of course; one might also argue that once the sovereign fails in his obligation to provide peace, the members of society are no longer obligated to obey him. The basis of obligation in Hobbes is not my central concern here, though, so I will not explore this in any depth.

6- Tom Sorell's contribution to this special edition makes a strong case for an undivided sovereign as the central message of Hobbes' thinking on law and politics. Patricia Springborg, in her reading of the Elements, also makes such an argument.

7- For a critical response to this legalism, there has been an effort to construct what is called political constitutionalism, which highlights the importance of legislatures, law making and republicanism as opposed to the legal liberalism of Dworkin and others (Bellamy 2008).

8- Gabriella Slomp argues that the politics of glory is a crucial and yet under explored element of Hobbes thought. Interestingly, she also finds in Hobbes a strong individualism, though her analysis points in other directions than Flathmans; Slomp 2000.

9- Michael Williams develops a parallel account of Hobbes in his construction of the realist tradition in international relations; see Williams 2005.

\section{$\underline{\text { Note on Contributor }}$}

Anthony F Lang, Jr holds a Chair in International Political Theory and directs the Centre for Global Constitutionalism at the University of St Andrews. His work focuses on the intersection of law, politics and ethics at the global level. He has published articles and book chapters on global constitutionalism, responsibility, punishment, humanitarian intervention, and the just war tradition. His most recent publication is International Political Theory: An Introduction (Palgrave, 2014).

\section{$\underline{\text { References }}$}

Arendt, Hannah. 1961. "What is Authority" pp. 91-142 in Arendt, Between Past and Future. New York: Penguin Publishers 
Bain, William. 2015. "Thomas Hobbes as a Theorist of Anarchy: A Theological Interpretation" History of European Ideas 41, 1: 13-28

Beardsworth, Richard. 2013. Cosmopolitanism and International Relations Theory. Cambridge: Polity Press.

Beitz, Charles. 1999. Political Theory and International Relations, New Edition. Princeton: Princeton University Press.

Brown, Garrett Wallace. 2009. Grounding Cosmopolitanism: From Kant to the Idea of a Cosmopolitan Constitution. Edinburgh: Edinburgh University Press.

Dyzenhaus, David. 2010. "Hobbes's Constitutional Theory” pp 453-480 in Thomas Hobbes, Leviathan, edited by Ian Shapiro. New Haven: Yale University Press.

Dyzenhaus, David. 2014. "Hobbes on the International Rule of Law" Ethics \& International Affairs 28, 1: 53-64

Dyzenhaus, David and Thomas Poole, eds., Hobbes and the Law. Cambridge: Cambridge University Press, 2012.

Fassbender, Bardo. 2009. The United Nations Charter as the Constitution of the International Community/ Leiden: Matinus Nijhoff

Flathman, Richard. 1977. The Practice of Rights. Cambridge: Cambridge University Press.

Flathman, Richard. 1980. The Practice of Political Authority: Authority and the Authoritative. Chicago: University of Chicago Press.

Flathman, Richard. 1989. Toward a Liberalism Ithaca: Cornell University Press

Flathman, Richard. 1992. Wilful Liberalism: Voluntarism and Individuality in Political Theory and Practice Ithaca: Cornell University Press, 1992

Flathman, Richard. 1998. Reflections of a Would-be Anarchist: Ideals and Institutions of Liberalism Minneapolis: University of Minnesota Press.

Flathman, Richard. 2002. Thomas Hobbes: Skepticism, Individuality, and Chastened Politics, New Ed.. Lanham MD: Rowman and Littlefield.

Flathman, Richard. 2005. Pluralism and Liberal Democracy Baltimore: Johns Hopkins University Press.

Habermas, Jurgen. 2006. 'Does the Constitutionalization of International Law Still Have a Chance?' pp. 115-193 in The Divided West, edited and translated by Ciaran Cronin. Cambridge: Polity Press.

Hayden, Patrick. 2005. Cosmopolitan Global Politics. Burlington VT: Ashgate Publishers. 
Hobbes, Thomas. 2008 [1640] Elements of the Law, Natural and Politic, edited by J C A Gaskin. Oxford: Oxford University Press.

Hobbes, Thomas. 1968 [1651]. Leviathan. London: Penguin Classics

Hobbes, Thomas. 1971 [1681] A Dialogue between a Philosopher and a Student of the Common Laws of England. Edited by Joseph Cropsey. Chicago: University of Chicago Press.

Honnig, Bonnie and David Mapel, eds., 2002. Skepticism, Individuality and Freedom: The Reluctant Liberalism of Richard Flathman Minneapolis: University of Minnesota Press.

Koskenniemi, Martii. 2005. From Apology to Utopia: The Structure of International Legal Argument, Revised Edition. Cambridge: Cambridge University Press.

Lang, Jr. Anthony F. 2014. International Political Theory: An Introduction: London: Palgrave.

Loughlin, Martin. 2012. "The Political Jurisprudence of Thomas Hobbes” pp 5-21 in David Dyzenhaus and Thomas Poole, eds., Hobbes and the Law. Cambridge: Cambridge University Press.

May, Larry. 2013. Limiting Leviathan: Hobbes on Law and International Affairs. Oxford: Oxford University Press.

Slomp, Gabriella. 2000. Thomas Hobbes and the Political Philosophy of Glory. Basingstoke: St Martin's Press.

Strauss, Leo. 1936. The Political Philosophy of Hobbes: Its Basis and its Genesis. Translated by Elsa M. Sinclair. Oxford: Oxford University Press.

Tully, James. 1993. An Approach to Political Philosophy: Locke in Contexts. Cambridge: Cambridge University Press.

Tully, James. 1995. Strange Multiplicity: Constitutionalism in an Age of Diversity. Cambridge: Cambridge University Press.

Tully, James, et al. 2014. On Global Citizenship: James Tully in Dialogue. London: Bloomsbury.

Warrender, Howard. 1957. The Political Philosophy of Hobbes: His Theory of Obligation. Oxford: Oxford University Press.

Williams, Michael. 2005. The Realist Tradition and the Limits of International Relations. Cambridge: Cambridge University Press. 